\title{
Najważniejsze doniesienia dotyczące nowotworów układu chłonnego z dorocznej konferencji Amerykańskiego Towarzystwa Onkologii Klinicznej w 2016 roku
}

\author{
The highlights of the lymphoid malignancies on the Annual Meeting \\ of the American Society of Clinical Oncology 2016
}

\author{
Ewa Kalinka-Warzocha \\ Oddział Chemioterapii, Wojewódzki Szpital Specjalistyczny im. Mikołaja Kopernika, Łódź
}

\begin{abstract}
Streszczenie
W pracy przedstawiono najciekawsze, zdaniem autorki, doniesienia z dorocznej konferencji Amerykańskiego Towarzystwa Onkologii Klinicznej w2016 roku. Podczas konferencji byty prezentowane wyniki badań ważnych dla diagnozowania, leczenia i prognozowania dotyczace między innymi chorych na chtoniaka rozlanego $z$ duzych komórek $B$, chtoniaka grudkowego, chtoniaka z komórek ptaszcza i chtoniaka Hodgkina.
\end{abstract}

Słowa kluczowe: chłoniak, leczenie, czynniki prognostyczne

Hematologia 2016; 7, 2: 117-127

\begin{abstract}
This paper presents the most interesting, according to the author's opinion, trial results presented at the American Society of Clinical Oncology Annual Meeting in 2016. Many study results were presented, most of them important for diagnostics, treatment and prognosis of patients with diffuse large B-cell lymphoma, follicular lymphoma, mantle cell lymphoma and Hodgkin lymphoma and others.
\end{abstract}

Key words: lymphoma, treatment, prognostic factors

Hematologia 2016; 7, 2: 117-127

\section{Wprowadzenie}

Doroczna konferencja Amerykańskiego Towarzystwa Onkologii Klinicznej (ASCO, American Society of Clinical Oncology) odbyła się w czerwcu 2016 roku w Chicago. Choć podczas konferencji ASCO są prezentowane głównie prace dotyczące guzów litych, to każdego roku pojawiają się w jej trakcie liczne, wartościowe doniesienia na temat nowotworów hematologicznych, w tym chłoniaków.
Chłoniak rozlany z dużych komórek B

W trakcie tegorocznej konferencji ASCO Witzig i wsp. [1] zaprezentowali wyniki randomizowanego, przeprowadzonego metodą podwójnie ślepej próby, badania III fazy PILLAR-2 (A randomized, double-blind, placebo-controlled, phase III study of adjuvant everolimus in poor-risk diffuse large B-cell lympho$m a$ ), służącego ocenie adjuwantowego leczenia ewerolimusem w porównaniu ze stosowaniem

Adres do korespondencji: Ewa Kalinka-Warzocha, Oddział Chemioterapii, Wojewódzki Szpital Specjalistyczny im. Mikołaja Kopernika, ul. Pabianicka 62, 93-513 Łódź, tel. 4268956 00, faks 4268956 01, e-mail: ewakalinka@wp.pl 


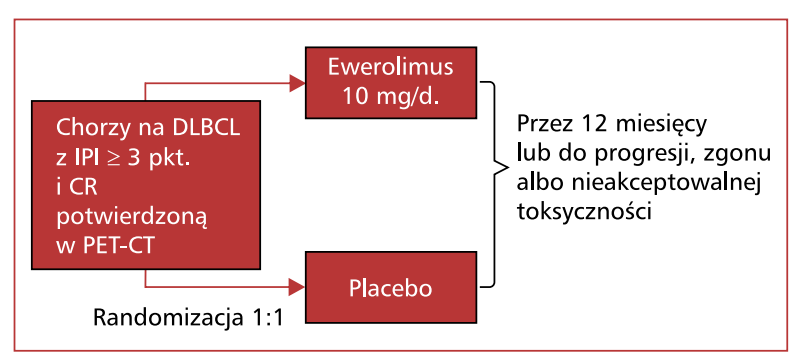

Rycina 1. Schemat badania PILLAR-2; DLBCL - chłoniak rozlany z dużych komórek B; IPI - Międzynarodowy Indeks Prognostyczny; CR - całkowita remisja; PET-CT - pozytonowa tomografia emisyjna-tomografia komputerowa

Figure 1. The schema of the PILLAR-2 study; DLBCL - diffuse large B-cell lymphoma; IPI - International Prognostic Index; CR - complete remission; PET-CT positron emission tomography-computed tomography

placebo u chorych na chłoniaka rozlanego $z$ dużych komórek B (DLBCL, diffuse large B-cell lymphoma) wysokiego ryzyka. Zgodnie $z$ koncepcją badania $\mathrm{u}$ chorych na DLBCL wysokiego ryzyka, tj. z 3-5 punktów według Międzynarodowego Indeksu Prognostycznego (IPI, International Prognostic Index) i w III/IV stopniu zaawansowania według klasyfikacji z Ann Arbor, którzy osiągnęli całkowitą remisję (CR) po zastosowaniu rytuksymabu (R) $\mathrm{w}$ połączeniu $z$ chemioterapią pierwszej linii, roczne leczenie ewerolimusem doprowadzi do redukcji ryzyka nawrotu. Schemat badania przedstawiono na rycinie 1 . Chorych poddano randomizacji, w proporcji 1:1, do terapii ewerolimusem $\mathrm{w}$ dawce $10 \mathrm{mg} /$ dobę lub stosowania placebo przez rok lub do progresji, nieakceptowalnej toksyczności albo zgonu. Dawka ewerolimusu odpowiada standardowo zarejestrowanej i szeroko stosowanej u pacjentów z jasnokomórkowym rakiem nerki. Głównym punktem końcowym badania była ocena przeżycia wolnego od choroby (DFS, disease-free survival). Cele drugorzędowe obejmowały ocenę przeżycia całkowitego (OS, overall survival), przeżycia związanego $z$ chłoniakiem (LSS, lymphoma-specific survival) i bezpieczeństwa stosowanego leczenia.

Po czasie obserwacji, którego mediana wyniosła 50,4 miesiąca (zakres 24,0-76,9 miesiąca), stwierdzono, że spośród 742 objętych randomizacją chorych leczenie zgodnie $z$ protokołem zakończyło $177(48 \%)$ w grupie leczonej ewerolimusem i 249 (67\%) chorych w grupie przyjmującej placebo. W całej populacji $47 \%$ chorych miało 65 lat lub więcej, $50 \%$ stanowili mężczyźni, a u $42 \%$ chorych wartość IPI oceniono na 4 lub 5. Adjuwantowe leczenie
Tabela 1. Wartości parametrów przeżycia w badaniu PILLAR-2

Table 1. Survival parameters in the PILLAR-2 trial

\begin{tabular}{|l|c|}
\hline Wartości parametrów & $\begin{array}{c}\text { Ewerolimus } \text { v. placebo } \\
\text { Iloraz szans (95-proc. } \mathrm{CI})\end{array}$ \\
\hline Przeżycie wolne od choroby \\
\hline Cała grupa $(\mathrm{n}=742)$ & $0,92(0,69-1,22)^{*}$ \\
\hline IPI 4 lub 5 $(\mathrm{n}=313)$ & $0,65(0,42-1,01)$ \\
\hline Mężczyźni $(\mathrm{n}=372)$ & $0,68(0,45-1,05)$ \\
\hline Przeżycie całkowite & \\
\hline Cała grupa $(\mathrm{n}=742)$ & $0,75(0,51-1,10)$ \\
\hline IPI 4 lub 5 $(\mathrm{n}=313)$ & $0,63(0,37-1,07)$ \\
\hline Mężczyźni $(\mathrm{n}=372)$ & $0,55(0,32-0,94)$ \\
\hline Przeżycie związane $\mathrm{z}$ chłoniakiem \\
\hline (n= 742) & $0,64(0,39-1,04)$ \\
\hline
\end{tabular}

${ }^{*} \log$-rank $\mathrm{p}=0,276 ; \mathrm{Cl}$ (confidence interval) - przedział ufności; IPI (International Prognostic Index) - Międzynarodowy Indeks Prognostyczny

ewerolimusem nie poprawiło DFS ( $\mathrm{p}=0,276$, test log-rank). Odsetki 2-letniego DFS wyniosły $78 \%$ $\mathrm{w}$ grupie leczonej ewerolimusem i $77 \%$ w grupie leczonej placebo. Obserwowano trendy na korzyść ewerolimusu (zwłaszcza w podgrupie mężczyzn i chorych $z$ IPI 4 lub 5) w odniesieniu do OS i LSS, ale nie osiągnęly one poziomu istotności statystycznej (tab. 1). Toksyczność 3.-4. stopnia według Swiatowej Organizacji Zdrowia (WHO, World Health Organization) była częstsza u pacjentów leczonych ewerolimusem i obejmowała głównie neutropenię, zapalenie błony śluzowej jamy ustnej, spadek liczby limfocytów CD4+, limfopenię i niedokrwistość.

Badanie PILLAR-2 jest zatem badaniem negatywnym, choć określenie roli adjuwantowego leczenia u chorych na DLBCL $z$ IPI 4 lub 5 wydaje się uzasadnione. Niewątpliwie oczekiwanym badaniem jest badanie randomizowane III fazy REMARC (Double blind randomized phase III study of lenalidomide maintenance versus placebo in responding elderly patients with DLBCL and treated with R-CHOP in first line) poświęcone ocenie wartości leczenia podtrzymującego lenalidomidem w podobnej grupie chorych.

Kolejne ciekawe wyniki przedstawili Lugtenburg i wsp. - badacze HOVON i Grupy Nordic Lymphoma Group (streszczenie 7504) [2]. Przesłanką do przeprowadzenia tego badania był brak jednoznacznych danych potwierdzających optymalny schemat terapii za pomocą $\mathrm{R} u$ chorych na DLBCL. Celem badania III fazy była ocena skuteczności wczesnej intensyfikacji leczenia R ze schematem CHOP (cyklofosfamid, doksorubicyna, winkrystyna, prednizon) podawanym w 14-dnio- 


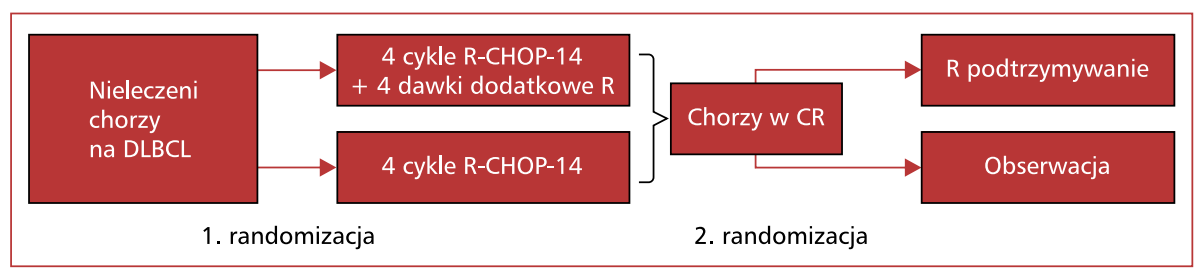

Rycina 2. Schemat badania HOVON-Nordic Lymphoma Group; DLBCL — chłoniak rozlany z dużych komórek B; R-CHOP - rytuksymab, cyklofosfamid, doksorubicyna, winkrystyna, prednizon; CR - całkowita remisja

Figure 2. The schema of the HOVON-Nordic Lymphoma Group trial; DLBCL — diffuse large B-cell lymphoma; $\mathrm{R}-\mathrm{CHOP}$ - rituximab, cyclophosphamide, doxorubicin, vincristine, prednisone; $\mathrm{CR}$ - complete remission

wych (R-CHOP-14) odstępach z leczeniem podtrzymującym R lub bez niego u chorych na DLBCL. $\mathrm{W}$ pierwszej fazie badania porównywano skuteczność 4 cykli R-CHOP-14 z 4 dodatkowymi podaniami R w trakcie tych 4 cykli lub bez dodatkowych podań R. Następnie dokonywano oceny skuteczności i chorych w CR poddawano randomizacji do podtrzymywania za pomocą $R$ lub obserwacji (ryc. 2). Wyniki prezentowane na konferencji ASCO 2016 dotyczą wyników pierwszej randomizacji.

Do badania włączono 575 chorych na DLBCL w stopniu zaawansowania II-IV według klasyfikacji z Ann Arbor, w wieku 18-80 lat. Randomizacja dotyczyła dołączenia do 4 cykli R-CHOP-14 dodatkowej dawki $\mathrm{R}$ wynoszącej $375 \mathrm{mg} / \mathrm{m}^{2}$ 8. dnia każdego cyklu. U chorych powyżej 65 lat obowiązkowa była prefaza; obligatoryjnie profilaktycznie podawano czynnik stymulujący tworzenie kolonii granulocytów (G-CSF, granulocyte-colony stimulating factor), kotrymoksazol oraz walacyklowir. Odpowiedź oceniano zgodnie $z$ kryteriami Lugano 2014, uznając za całkowitą remisję metaboliczną $(\mathrm{CRm})$ sytuację, w której w wyniku badania metodą pozytonowej tomografii emisyjnej-tomografii komputerowej (PET-CT, positron emission tomography-computed tomography) wskaźnik Deauville nie przekraczał 3. Głównym punktem końcowym badania był odsetek $\mathrm{CRm}$ po leczeniu indukującym. Mediana wieku chorych wyniosła 65 lat (zakres, 18-80 lat), 50\% chorych miało co najmniej 66 lat, a 52\% stanowili mężczyźni. U większości (57\%) chorych stwierdzono wysokie-pośrednie lub wysokie ryzyko według IPI skorygowanego względem wieku (aaIPI, age-adjusted IPI). Wyjściowa charakterystyka chorych była zrównoważona między badanymi grupami.

Nie stwierdzono istotnej różnicy w zakresie odsetka CRm między grupami $-84 \% \mathrm{CRm}$ w grupie poddanej terapii standardowej i $82 \%$ $\mathrm{CRm} w$ grupie leczonej eksperymentalnie (iloraz szans [OR, odds ratio $]=0,83$, 95-proc. przedział ufności [CI, confidence interval] 0,54-1,28; $\mathrm{p}=0,40)$. Obserwowane odsetki CRm u chorych poniżej i powyżej 65 . roku życia nie różniły się. Po obserwacji o medianie 49 miesięcy 3-letnie i 5-letnie przeżycia wolne od progresji (PFS, progression-free survival) wyniosły $74 \%$ i $68 \%$ w grupie poddanej terapii standardowej oraz $71 \%$ i $61 \%$ w w grupie leczonej eksperymentalnie (ryzyko względne $=1,23,95 \%$ CI $0,92-1,63 ; \mathrm{p}=0,16)$. Nie stwierdzono różnic w zakresie PFS w podgrupach chorych młodszych w porównaniu ze starszymi ani zależnie od płci. W podsumowaniu badania autorzy skonkludowali, że wczesna intensyfikacja R-CHOP-14 dodatkowymi dawkami R w okresie indukcji nie poprawiła odsetków $\mathrm{CRm}$, ani nie wpłynęła na PFS zarówno w całej populacji chorych, jak i w żadnej $z$ podgrup.

$Z$ kolej badacze $z$ Uniwersytetu Stanford ocenili czynniki związane $z$ wczesną identyfikacją chorych na DLBCL nieodpowiadających na leczenie (streszczenie 7511) [3]. Wiedząc, że odpowiedzi na leczenie pierwszej linii u chorych na DLBCL są różne, a brak odpowiedzi wiąże się $z$ niekorzystnym rokowaniem, Kurtz i wsp. postanowili sprawdzić, czy ocena krążącego DNA chłoniaka (ctDNA, circulating tumor DNA) po pierwszych cyklach leczenia stanowi czynnik predykcyjny dla uzyskania remisji po leczeniu pierwszej linii. Na pierwszym etapie badania sekwencjonowano germinalne DNA chłoniaka w celu zidentyfikowania swoistych dla chłoniaka mutacji somatycznych, którego obecność oceniano następnie w osoczu. Zmiany ctDNA w osoczu porównywano $z$ odpowiedzią uzyskaną na podstawie badania PET-CT; wynik ponizej $4 \mathrm{w}$ skali Deauville uznawano za CRm. W kohorcie treningowej u 12 chorych na DLBCL oceniono dynamikę ctDNA $\mathrm{w}$ trakcie 2 pierwszych cykli terapii (114 próbek, mediana 9 próbek na pacjenta). Już pierwsze wyniki dowiodły, że u chorych uzyskujących CRm poziomy ctDNA obniżały się w większym stopniu już 22 . dnia (1/ dzień drugiego cyklu) (redukcja 3,35-log v. 0,98-log; $\mathrm{p}=0,0014)$. Stwierdzono także, $\dot{\mathrm{z} e}$ 
u $5 / 5$ chorych $z$ redukcją ctDNA o ponad $2-\log$ obserwowano osiagnnięcie CR, a u7/7 chorych, którzy nie uzyskali takiej redukcji ctDNA, CRm nie obserwowano $(p=0,0013)$. Po przeanalizowaniu kohorty treningowej ustalono redukcję poziomu ctDNA o ponad 2-log jako punkt odcięcia dla kohorty rozszerzonej, do której włączono 33 chorych. W kohorcie rozszerzonej potwierdzono, że redukcja poziomu ctDNA o ponad 2-log jest istotnym czynnikiem predykcyjnym dla odsetków CRm $(75 \%$ v. $22 \%, \mathrm{p}=0,01)$, PFS ( $\mathrm{p}=0,002)$ i OS $(\mathrm{p}=0,001)$. Zmiana poziomu ctDNA wiązała się $z$ poprawą PFS $\mathrm{w}$ analizie wielowariancyjnej $(\mathrm{p}=0,003)$, w której uwzględniono IPI, komórkę pochodzenia i wcześniejsze leczenie. W podgrupie 8 chorych, u których doszło do niepowodzenia leczenia, poziom ctDNA wyprzedzał progresję radiologiczną o 148 dni (mediana). We wnioskach pracy autorzy wskazują, że ocena ctDNA dynamicznie zmienia się w trakcie leczenia, a spadek poziomu w osoczu o ponad 2 -log w czasie 2 pierwszych cykli terapii wiąże się $z$ odpowiedzią i wskaźnikami przeżycia. Autorzy jednak sami podkreślają, że konieczne są dalsze badania nad dynamiką zmian ctDNA, co może pozwoli na wczesną intensyfikację terapii u tych źle rokujących chorych.

Crump i wsp. w badaniu SCHOLAR-1 (International, multi-cohort retrospective non-Hodgkin lymphoma research) (streszczenie 7516) poddali analizie chorych na opornego DLBCL [4]. Dane z piśmiennictwa wskazują, że pacjenci z nawrotowym/ /opornym DLBCL stanowią heterogenną grupę, w której chorzy z pierwotną opornością (rDLBCL, refractory $D L B C L$ ) rokują najgorzej. Wielokohortowe badanie SCHOLAR-1 zaplanowano, by ocenić przebieg rDLBCL i określić cele dla przyszłych badań w tej grupie chorych. Wszyscy chorzy zakwalifikowani do badania musieli być leczeni przeciwciałem anty-CD20 (chyba że nie obserwowano ekspresji antygenu CD20 na komórkach chłoniaka) oraz antracyklinami w co najmniej jednej linii terapii. Chorzy włączeni do tego badania zostali zakwalifikowani do rDLBCL, jeśli ich najlepszą odpowiedzią na leczenie była progresja (PD, progressive disease) lub stabilizacja choroby (SD, stable disease) trwająca krócej niż 12 miesięcy po co najmniej 4 cyklach leczenia pierwszej linii lub co najmniej 2 cyklach w kolejnych liniach leczenia albo jeśli wystąpił u nich nawrót po czasie krótszym niż 12 miesięcy po przeszczepieniu autologicznych krwiotwórczych komórek macierzystych (auto-HSCT, autologous hematopoietic stem cell transplantation). Bazą danych do poszukiwań chorych do badania SCHOLAR-1 były grupy pacjentów $z$ czterech badań: dwóch ba- dań III fazy (LYSARC-CORAL i Canadian Cancer Trials Group-LY.12), dwóch badań obserwacyjnych (MD Anderson Cancer Center [MDACC] oraz Mayo Clinic/University of Iowa [MC/IA] Specialized Program of Research Excellence). Oceniano odsetki odpowiedzi (RR, response rate) i OS, licząc od dnia rozpoczęcia leczenia ratunkowego.

Do analizy włączono 861 chorych na DLBCL, identyfikując wśród nich 597 chorych $z$ rDLBCL. Stwierdzono, że RR wynosił 19-36\%, przy czym odsetek CR mieścił się w przedziale $2-18 \%$, a PR - 13-3\%. U 142 pierwotnie opornych chorych RR wyniósł 24-28\%, u 306 chorych opornych na więcej niż 2 linie leczenia - 19-36\%, u 149 chorych z nawrotem w czasie krótszym niż 12 miesięcy po auto-HSCT $-11-35 \%$. Wyniki badania wskazują na heterogenność rDLBCL, a krótka mediana OS wskazuje na konieczność zintensyfikowania badań w tej grupie chorych.

Kolejnym interesującym zagadnieniem u chorych na DLBCL jest wpływ infekcji wirusem zapalenia wątroby typu C (HCV, hepatitis C virus) na przeżycie. Piśmiennictwo potwierdza od wielu lat, że u chorych $z$ infekcją HCV częstość zachorowania na chłoniaki nie-Hodgkina jest większa niż w populacji ogólnej. Dowody ukazujące korelację skutecznego leczenia infekcji HCV $z$ aktywnością chłoniaków indoletnych są spójne, potwierdzając nawet wieloletnie CR po wyłącznym skutecznym leczeniu przeciwwirusowym (AVT, antiviral therapy). Hosry i wsp. [5] ocenili rolę AVT u chorych na DLBCL $z$ infekcją HCV (streszczenie 7540).

Do analizy włączono wszystkich chorych na DLBCL $z$ towarzyszącą infekcją HCV $z$ jednej instytucji leczonych od czerwca 2004 roku do maja 2014 roku. Następnie do każdego zidentyfikowanego chorego dobrano 3 , na podstawie roku zachorowania na DLBCL, wieku, płci i zaawansowania według klasyfikacji Ann Arbor. Pacjentów podzielono na trzy podgrupy w zależności od ekspozycji na AVT - nigdy niepoddanych AVT, poddanych AVT przed rozpoznaniem DLBCL, grupę kontrolną bez infekcji HCV. W tych trzech grupach badano: odpowiedź na chemioterapię pierwszej linii, odsetek nawrotów, odpowiedź w czasie ostatniej wizyty, odsetki 5-letniego OS, 3-letniego PFS i 3-letniego DFS. Leczenie przeciwwirusowe opierało się na schematach zawierających interferon.

Do badania włączono 304 chorych (76 zainfekowanych HCV i 228 z grupy kontrolnej). W grupie $z$ infekcją HCV stwierdzono nieznamiennie częstsze występowanie lokalizacji pozawęzłowych $(79 \%$ v. $72 \% ; \mathrm{p}=0,07) \mathrm{z}$ istotnie częstszymi lokaliza- 
cjami w górnym odcinku przewodu pokarmowego (42\% v. $24 \% ; \mathrm{p}=0,004)$. U chorych $\mathrm{HCV}(+)$ nigdy niepoddawanych AVT stwierdzono częstszą oporność na leczenie pierwszej linii niż w grupie kontrolnej $(33 \% v .17 \% ; \mathrm{p}=0,05) \mathrm{z}$ tendencją do częstszej progresji w porównaniu $z$ grupą kontrolną (50\% v. 32\%; $\mathrm{p}=0,09)$ i leczonej AVT (50\% v. 27\%; $\mathrm{p}=0,06)$. Chorzy nigdy niepoddani AVT osiaggali gorsze odsetki 5-letniego OS w porównaniu $z$ grupą kontrolną (OR 4,88, 95\% CI, 1,55-15,36; $\mathrm{p}=0,006)$. Leczenie przeciwwirusowe poprawiło odsetki 5-letniego OS u chorych $\mathrm{z}$ infekcją $\mathrm{HCV}$ (ryzyko względne 0,19 [95\% CI, 0,04-0,81]; $\mathrm{p}=0,02$ ). Wpływ AVT na 5-letnie OS najbardziej zaznaczył się u chorych $\mathrm{z}$ zajęciem górnego odcinka przewodu pokarmowego ( $77 \%$ v. $43 \%$ u chorych niepoddanych AVT; $\mathrm{p}=0,02)$. Nie stwierdzono istotnych różnic w zakresie odsetków nawrotów, PFS i DFS. $\mathrm{W}$ podsumowaniu stwierdzono, że leczenie infekcji HCV u chorych na DLBCL poprawia odsetki odpowiedzi na chemioterapię i 5-letnie OS, zwłaszcza $\mathrm{u}$ chorych $\mathrm{z}$ zajęciem górnego odcinka przewodu pokarmowego.

W ocenie autorki niniejszego artykułu powyższa praca powinna stanowić dodatkowy argument do stosowania AVT u chorych na DLBCL, zwłaszcza że dostępność do nowoczesnej terapii infekcji HCV uległa od kilku miesięcy znaczącej poprawie. Wobec tego szczególnego znaczenia nabiera rutynowa diagnostyka w kierunku HCV u chorych na chłoniaki.

\section{Chłoniak ośrodkowego układu nerwowego}

Rubenstein i wsp. (streszczenie 7502) ocenili skuteczność i bezpieczeństwo lenalidomidu w leczeniu podtrzymującym nawrotu CD20+ DLBCL ośrodkowego układu nerwowego (OUN) w kilku kohortach badania I fazy [6]. Lenalidomid podawano chorym w dawce 10, 20 lub $30 \mathrm{mg}$. Oceniano także przenikanie tego leku do płynu mózgowo-rdzeniowego (CSF, cerebrospinal fluid) oraz możliwość podania dożylnego i dokomorowego rytuksymabu, a także czas do progresji (TTP, time to progression). Jedną $z$ badanych kohort stanowiło 13 chorych na DLBCL $-8 z$ pierwotnym oraz $5 z$ wtórnym zajęciem OUN (mediana wieku 63 lata). U 8 z tych chorych stwierdzono więcej niż remisję częściową (PR, partial remission) po monoterapii lenalidomidem; u 4 chorych PR utrzymała się dłużej niż 9 miesięcy, a u 2 powyżej 1,8 roku. W niezależnej kohorcie 12 chorych $z$ nawrotem DLBCL OUN ( $10 \mathrm{z}$ zajęciem pierwotnym, $2 \mathrm{z}$ wtórnym; mediana wieku 70 lat) stosowano monoterapię lenalidomidem (5-10 mg) jako podtrzymywanie po leczeniu ratunkowym. Po obserwacji o medianie przekraczającej 18 miesięcy stwierdzono, że u 5 chorych remisja utrzymuje się ponad 2 lata. Stężenie lenalidomidu w CSF w komorach było najwyższe po dawce $20 \mathrm{mg}$. Lenalidomid dobrze przechodzi do CSF i jest aktywny u chorych $z$ nawrotem DLBCL OUN. Leczenie podtrzymujące lenalidomidem $\mathrm{w}$ tym badaniu wydłuża TTP po leczeniu nawrotu i opóźnia radioterapię OUN.

Prezentowane badanie nie może być podstawą zmiany standardu leczenia nawrotów DLBCL OUN, ale — zważywszy na skrajnie niekorzystne rokowanie $\mathrm{w}$ tej grupie chorych - powinno stanowić przyczynek do zaplanowania dalszych badań w tym zakresie.

\section{Chłoniak z komórek płaszcza}

W chłoniaku $\mathrm{z}$ komórek płaszcza (MCL, mantle cell lymphoma) ciągle poszukuje się nowych czynników prognostycznych i predykcyjnych. Badanie Scotta i wsp. (streszczenie 7510) [7] zaplanowano $\mathrm{w}$ celu zwalidowania nowego czynnika prognostycznego opartego na profilu ekspresji genów. Do tej pory najbardziej wartościowym, uznanym zestawem biomarkerów był „podpis proliferacyjny" stworzony na podstawie ekspresji genów w świeżo mrożonym materiale tkankowym. W projekcie Scotta i wsp. zakładano stworzenie kohorty treningowej i walidacyjnej dla „podpisu proliferacyjnego" na podstawie analizy RNA, uzyskanego $z$ rutynowo dostępnych bloczków tkankowych utrwalanych parafiną i zatapianych w parafinie (FFPE, formalin-fixed and paraffin-embedded). W kohorcie treningowej analizowano material z FFPE $z$ zastosowaniem platformy Bio NanoString $z$ analizą ekspresji genów za pomocą mikromacierzy Affymetrix U133 w porównaniu $z$ analizą materiału świeżo mrożonego jako „złotego standardu”. W pierwszej fazie badania oceniono współczynniki dla ekspresji genów i punkty odcięcia w celu wyodrębnienia grup niskiego, pośredniego i wysokiego ryzyka na FFPE biopsji węzłów pochodzących od 110 chorych leczonych według schematu R-CHOP w British Columbia Cancer Agency. Pięćdziesięciu dziewięciu $z$ tych chorych, w wieku do 65 lat, było leczonych według zasady intent-to-treat, z planowaną konsolidacją przeszczepieniem autologicznych krwiotwórczych komórek macierzystych (auto-HSCT, autologous hematopoietic stem cell transplantation) (grupa ASCT-ITT). Wartość IPI (mIPI, mantle cell lymphoma IPI) była znana u 95 ze 110 chorych.

W badaniu za pomocą MCL55, testowanego zestawu ekspresji 16 genów „podpisu proliferacyjnego”, 


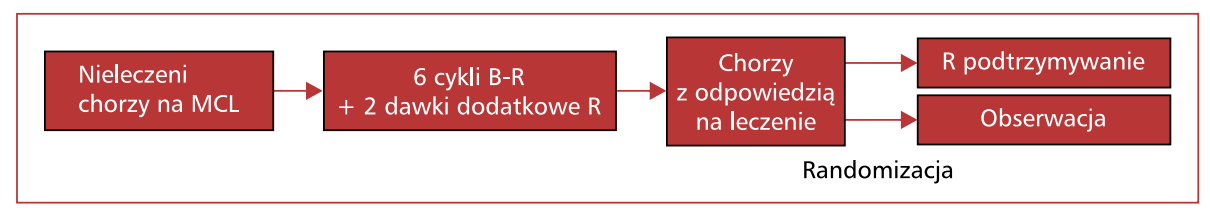

Rycina 3. Schemat badania MAINTAIN; MCL — chłoniak z komórek płaszcza; B-R — bendamustyna, rytuksymab

Figure 3. The schema of the MAINTAIN trial; $M C L$ - mantle cell lymphoma; $B-R$ - bendamustine, rituximab

osiągnięto wystarczającą jakość ekspresji genów i pozwoliło przyporządkować wynik i grupę ryzyka dla 108/110 (98\%) archiwalnych FFPE, włączając chorych do grup wysokiego (26\%), pośredniego (29\%) i niskiego ryzyka (45\%), $z$ istotnie różnym OS. Mediana OS wyniosła odpowiednio 1,1, 2,6 oraz 8,6 roku (log-rank $\mathrm{p}<0,001$ ). W grupie ASCT-ITT mediana OS wyniosła odpowiednio 1,4 i 5,9 dla dwóch pierwszych grup, a dla trzeciej grupy nie osiągnięto mediany OS (log-rank $\mathrm{p}<0,001)$. W analizie wielowariancyjnej grupy ryzyka przyporządkowane za pomocą MCL55 i mIPI były niezależnie związane $z$ OS w całej kohorcie ( $<<0,001$ dla obu wskaźników). Według autorów zatem nowo opracowany i zwalidowany MCL55 dla biopsji FFPE pozwala, za mocą ,podpisu proliferacyjnego", zdefiniować grupy ryzyka chorych na MCL w odniesieniu do OS, w sposób niezależny od mIPI. Praca ta wydaje się mieć przyszłość aplikacyjną ze względu na możliwość wykorzystania FFPE dostępnych w przypadku większości chorych na MCL. Wskaźnik MCL55 wymaga jednak wcześniej zwalidowania w prospektywnych badaniach klinicznych.

Rummeliwsp. przedstawili badanie MAINTAIN (streszczenie nr 7503), którego celem było określenie roli leczenia podtrzymującego za pomocą $R$ $\mathrm{u}$ chorych na MCL po leczeniu indukującym bendamustyną (B) z R [8]. Analiza obejmowała chorych na MCL wlączonych do badania StiL (Study Group Indolent Lymphomas). Do badania włączano pacjentów $z$ nieleczonym MCL w stadium II ( $z$ masą bulky $>7 \mathrm{~cm}$ ), III lub IV według klasyfikacji z Ann Arbor. Głównym punktem końcowym był PFS, a drugorzędowymi - RR, TTP, przeżycie wolne od zdarzeń (EFS, event-free survival), OS oraz toksyczność. Leczenie indukujące obejmowało maksymalnie 6 cykli R-B z 2 dodatkowymi dawkami $R$, a następnie oceniano odpowiedź na leczenie. Chorych, którzy uzyskali odpowiedź, poddawano randomizacji do podtrzymującego leczenia za pomocą $\mathrm{R}\left(375 \mathrm{mg} / \mathrm{m}^{2}\right.$ co 2 miesiące przez 2 lata) lub obserwacji (ryc. 3). Randomizacją objęto 120 chorych - 59 (49\%) do grupy leczonej R i 61 (51\%) do obserwacyjnej. Gru- py były zrównoważone w zakresie charakterystyki chorych. Mediana wieku chorych wyniosła 70 lat, a mediana obserwacji - 54,2 miesiąca. Między grupami nie stwierdzono istotnych różnic w zakresie PFS ( $\mathrm{p}=$ 0,130, 47 zdarzeń, współczynnik ryzyka $[\mathrm{HR}$, hazard ratio $]=0,64,95 \%$ CI 0,36-1,14). Mediana PFS u chorych leczonych R nie została jeszcze osiagnięta, a w grupie obserwacyjnej wyniosła 54,7 miesiąca. Mediana OS wyniosła 69,6 miesiąca $\mathrm{w}$ grupie leczonej $\mathrm{R}$ i nie została jeszcze osiagnięta w grupie obserwacyjnej ( $\mathrm{p}=0,271,27$ zdarzeń, HR 1,53, 95\% CI 0,73-3,32). Po czasie obserwacji, którego mediana wynosiła 4,5 roku, nie stwierdzono statystycznie istotnych różnic w zakresie PFS i OS, ale autorzy podkreślili, że ostateczne wnioski $z$ badania wymagają dłuższej obserwacji.

Analiza Rummel i wsp. [8] dostarcza kolejnych argumentów na rzecz jak najskuteczniejszej terapii indukującej u starszych chorych na MCL. W przypadku zastosowaniu skutecznej indukcji leczenie podtrzymujące nie ma już takiego znaczenia. Ten argument był często podnoszony przez badaczy projektu StiL w odniesieniu do chłoniaka grudkowego (FL, follicular lymphoma). Uważali oni, że indukcja remisji za pomocą schematu R-B daje na tyle dobre wyniki, że leczenie podtrzymujące nie jest już potrzebne. Argumenty te były szczególnie chętnie podnoszone wobec autorów badania PRIMA (Rituximab maintenance for 2 years in patients with high tumour burden follicular lymphoma responding to rituximab plus chemotherapy), w którym dominowały inne schematy indukujące.

\section{Chłoniak grudkowy}

Od lat poszukuje się sposobu poprawienia wyników leczenia chorych na FL. W badaniu E2408 Evens i wsp. [9] oceniali, czy dodanie bortezomibu (V) do standardowej indukcji za pomocą schematu B-R (bendamustyna, rytuksymab) poprawi odsetek CR u chorych na FL wysokiego ryzyka, a także, czy dodanie lenalidomidu do $\mathrm{R}$ wpłynie na czas trwania remisji. Schemat badania przedstawiono na rycinie 4. 


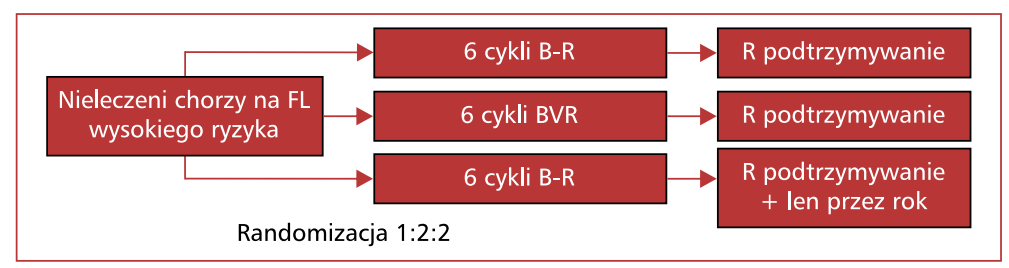

Rycina 4. Schemat badania E2408; FL — chłoniak grudkowy; B-R - bendamustyna, rytuksymab; BVR - bendamustyna, bortezomib, rytuksymab

Figure 4. The schema of the E2408 trial; FL — follicular lymphoma; B-R - bendamustine, rituximab; BVR — bendamustine, bortezomibe, rituximab

Chorych $z$ nieleczonym FL G1/2 lub G3a wysokiego ryzyka według kryteriów Groupe d'Etudes des Lymphomes Folliculaires (GELF) i/lub FLIPI 3-5 poddano randomizacji do trzech grup. W grupie A chorzy otrzymywali leczenie indukujące według schematu B-R (6 cykli) z leczeniem podtrzymującym R przez 2 lata. W grupie B chorzy otrzymywali leczenie indukujące według schematu BVR (bendamustyna, bortezomib, rytuksymab), $z$ bortezomibem $\mathrm{w}$ dawce $1,3 \mathrm{mg} / \mathrm{m}^{2} \mathrm{w}$ dniach 1., 4., 8., 11. dożylnie lub podskórnie ( 6 cykli) $z$ leczeniem podtrzymującym R przez 2 lata. W grupie C chorzy otrzymywali leczenie indukujące według schematu B-R (6 cykli) $z$ leczeniem podtrzymującym $\mathrm{R}$ przez 2 lata $\mathrm{w}$ połączeniu $z$ lenalidomidem w dawce $20 \mathrm{mg}$ /dobę przez rok. Odpowiedź oceniano za pomocą PET-CT, zgodnie $z$ kryteriami IWG (International Working Group) z 2007 roku. W prezentowanej na konferencji analizie przedstawiono wyniki dotyczące odsetka CR po leczeniu indukującym, co było głównym punktem końcowym badania. Porównano odsetki $\mathrm{CR}$ w grupie $\mathrm{B}$ względem połączonych danych w grupach A i C.

Pierwotnie do badania włączono 250 chorych na FL wysokiego ryzyka, ale 28 pacjentów wyłączono $z$ powodu nierozpoczęcia leczenia $(n=5)$, niespełnienia kryteriów włączenia $(n=8)$, braku centralnej weryfikacji oceny patologicznej $(n=15)$. Prezentowana analiza objęła 222 chorych (85 w grupie leczonej wg schematu BVR i $137 \mathrm{w}$ grupie leczonej wg schematu B-R); grupy były zrównoważone pod względem charakterystyki wyjściowej. W całej badanej grupie ryzyko według GELF było wysokie u 92\% chorych; FLIPI 3-5 stwierdzono u 55\% chorych; stan sprawności według ECOG wynosił 0 u 55\%, 1 u $41 \%$ i 2 u $3 \%$ chorych; u 55\% chorych stwierdzono zajęcie szpiku kostnego; zaawansowanie w stopniu II występowało u 7\%, w stopniu III u $27 \%$, a w stopniu IV u $66 \%$ chorych. Zaplanowanych 6 cykli podano $86 \%$ chorym, bez istotnych różnic między grupami. Całkowity odsetek odpowiedzi (ORR, overall response rate) wyniósł
91\% u leczonych według schematu BVR i $90 \%$ u leczonych zgodnie ze schematem B-R, natomiast odsetek CR wyniósł, odpowiednio, $74 \%$ i $58 \%$ $(\mathrm{p}=0,016)$. Przyczyną przerwania leczenia przed 6. cyklem w grupach BVR i BR były, odpowiednio, progresja choroby $-4 \% \mathrm{w}$ porównaniu $\mathrm{z} 7 \% \mathrm{i}$ toksyczność $-6 \%$ w porównaniu z $4 \%$. Najczęstszymi działaniami niepożądanymi 3. i 4. stopnia według WHO w grupach BVR i B-R były, odpowiednio: neutropenia $-35 \%$ i $30 \%$, neuropatia czuciowa - 12\% i 1\%, małopłytkowość - 10\% i 5\%, zespół zmęczenia - 6\% i 7\%, gorączka neutropeniczna $3 \%$ i $5 \%$, biegunka - 5\% i $1 \%$. Neuropatia czuciowa 3 . stopnia według WHO wystąiła w $91 \%$ przypadków u chorych leczonych B podawanym dożylnie. Częstość neuropatii czuciowej 3. stopnia według WHO w grupie leczonej B podawanym dożylnie i podskórnie wyniosła, odpowiednio, $14 \%$ i $4 \%$ $(\mathrm{OR}=3,7 ; \mathrm{p}=0,2)$. W czasie leczenia indukującego wystąpiły 3 zgony -2 z powodu chłoniaka; wszystkie w grupie $\mathrm{C}$.

Podsumowując, w badaniu E2408, w jego pierwszej analizie, potwierdzono, że leczenie indukujące nieleczonych chorych na FL wysokiego ryzyka za pomocą schematu BVR pozwala uzyskać istotnie wyższy odsetek CR niż leczenie według schematu B-R. Wyniki dotyczące wskaźników przeżycia oraz roli lenalidomidu w leczeniu podtrzymującym wymagają dłuższej obserwacji.

\section{Chłoniaki T-komórkowe}

Trumper i wsp. (streszczenie 7500) [10] przedstawili wyniki badania ACT-2 u 116 starszych chorych na chłoniaki $z$ obwodowych komórek $\mathrm{T}$ (PTCL, peripheral T-cell lymphoma). To randomizowane badanie III fazy przeprowadzono w latach 2007-2013; chorych poddano randomizacji do 6 cykli CHOP lub 6 cykli A-CHOP $z$ alemtuzumabem (A) w odstępach 14-dniowych $z$ profilaktyką G-CSF. Chorzy otrzymali łączną dawkę A wynoszącą 
$360 \mathrm{mg}$ (pierwszych 39 chorych), a następnie $120 \mathrm{mg}$. Badanie zaplanowano, aby wykazać 15-procentową poprawę EFS. Mediana wieku w badanej grupie wyniosła 69 lat; $58 \%$ stanowili mężczyźni. Wśród rozpoznań histopatologicznych dominował chłoniak angioimmunoblastyczny $z$ komórek $T$ (AITL, angioimmunoblastic T-cell lymphoma), pozostałą część stanowili chorzy na chłoniaka z obwodowych komórek T, bliżej nieokreślonego (PTCL NOS, peripheral T-cell lymphoma, not otherwise specified) $-39 \%$, chłoniaki anaplastyczne $z$ dużych komórek (ALCL, anaplastic large cell lymphoma) $6 \%$ oraz inne podtypy PTCL $-14 \%$. Całość zaplanowanego leczenia podano $79 \%$ chorych w grupie poddanej terapii według schematu CHOP i 57\% w grupie poddanej terapii według schematu A-CHOP. W grupie A-CHOP obserwowano częstszą toksyczność hematologiczną 3.-4. stopnia (leukopenia i małopłytkowość) według WHO, co skutkowało większą częstością infekcji 3. lub wyższego stopnia $(40 \%$ v. 21\%). Po 3 latach nie stwierdzono różnic w zakresie EFS, PFS ani OS. Autorzy wnioskują, że dodanie A do CHOP u chorych starszych $z$ PTCL zwiększa odsetki odpowiedzi $(60 \%$ CR v. 43\% w grupie leczonej wg schematu CHOP), ale wskaźniki przeżycia nie różnią istotnie, prawdopodobnie z powodu nasilonej toksyczności mimo profilaktyki zakażeń wirusowych.

\section{Odległe skutki leczenia chłoniaków}

Niezwykle wartościową analizę przedstawili Mounier i wsp. w badaniu Simonal (streszczenie 7518) [11] służącym ocenie późnej toksyczności leczenia chorych na chłoniaki nie-Hodgkina (NHL, non-Hodgkin lymphoma) na podstawie analizy 12 badań francuskiej grupy LYSA (Collaborative Lymphoma Study Association). Powszechnie wiadomo, że chorzy po leczeniu $z$ powodu NHL są obarczeni podwyższonym ryzykiem rozwoju nowotworów wtórnych i późnej toksyczności, obejmującej przede wszystkim choroby układu sercowo-naczyniowego i neuropsychiatryczne. Dane dotyczące późnych powikłań leczenia za pomocą $R$ nie są szeroko znane. Dlatego w badaniu SIMONAL oceniono wpływ leczenia na późną chorobowość w obrębie licznej kohorty chorych $z$ długim okresem obserwacji po leczeniu. W 2015 roku do chorych uczestniczących w 12 kolejnych randomizowanych badaniach LYSA (1993-2007), przeprowadzonych u chorych na DLBCL i FL, wysłano formularze do oceny zespołu zmęczenia (MFI-20) i kwestionariusz samooceny sytuacji życiowej (LSQ). Spośród 8113 chorych włączonych do badań w czasie ostatniej obserwacji żyło 5247. Udało się ustalić adresy $3317 \mathrm{z}$ tych chorych, a kwestionariusze odesłało 1671 (50\%) chorych. Chorzy, którzy odesłali formularze, brali udział w późniejszych badaniach i częściej byli leczeni $\mathrm{R}$ niż chorzy, którzy nie odpowiedzieli na prośbę o odesłanie kwestionariuszy. Czynniki prognostyczne dla NHL i rodzaj chemioterapii nie różniły się między tymi dwiema grupami. W celu oceny czynników związanych $z$ zespołem zmęczenia zastosowano model regresji liniowej.

Zebrano dane dotyczące 906 mężczyzn i 765 kobiet (mediana wieku 64 lata; zakres 24-95 lat). U $28 \%$ rozpoznano $\mathrm{FL}$, a u $72 \%$ DLBCL; 811 chorych leczono chemioterapią według schematu CHOP, 518 wysokodawkową chemioterapią według schematu CHOP, a 342 z zaplanowaną z góry konsolidacją auto-HSCT. Rytuksymab podawano w skojarzeniu $\mathrm{z}$ chemioterapią $829(50 \%)$ chorym. Mediana obserwacji wyniosła 11 lat (zakres 5-23 lat). U 583 (35\%) chorych nie zaraportowano żadnej chorobowości. U pozostałych wystąpiły późne zdarzenia (1 do 7), w tym: sercowo-naczyniowe u $20 \%$, neuropsychiatryczne u $17 \%$, infekcje u $12 \%$, mięśniowo-szkieletowe u $11 \%$, płucne u $8 \%$, pokarmowe u $5 \%$ i wtórne nowotwory u $8 \%$. Leczenie za pomocą $\mathrm{R} w$ mniejszym stopniu wiązało się $z$ występowaniem wtórnych nowotworów $(6 \%$ v. $9 \%$, $\mathrm{p}=0,02)$ i chorób układu sercowo-naczyniowego (17 v. 23\%; $\mathrm{p}=0,006)$. $Z$ góry zaplanowana konsolidacja auto-HSCT wiązała się z częstszymi infekcjami (17 v. 11\%; p =0,002) i powikłaniami płucnymi (12 v. 7\%; p =0,005). Wiek powyżej 75 lat był jedynym czynnikiem wiążącym się ze zwiększoną częstością powikłań sercowo-naczyniowych i nowotworów wtórnych. U 1036 (64\%) chorych stwierdzono utrzymujący się zespół zmęczenia (MFI $\geq 40$ ). Nie stwierdzono związku tego zespołu $z$ żadnym rodzajem leczenia. Zwiększony poziom zmęczenia był związany $(\mathrm{p}<0,001)$ $z$ wiekiem, otyłością, chorobami układu sercowo-naczyniowego, płucnymi, mięśniowo-szkieletowymi i neuropsychiatrycznymi.

Autorzy skonkludowali, że SIMONAL to pierwsze badanie poświęcone raportowaniu odległych skutków leczenia NHL i potwierdzające pogorszenie stanu zdrowia. Skojarzenie chemioterapii z R nie nasila późnej toksyczności ani zespołu zmęczenia.

Zagadnienie późnych powikłań po leczeniu przeciwnowotworowym stanowi istotny problem - $z$ tego właśnie powodu chorzy wyleczeni $z$ nowotworu lub pozostający w wieloletniej remisji nie potrafią w pełni wrócić do swoich ról zawodowych, społecznych i rodzinnych, co prowadzi do znaczą- 
cego pogorszenia jakości ich życia. Dlatego znajomość odległych skutków leczenia jest elementem koniecznym w jego kompleksowym zaplanowaniu.

\section{Chłoniak Hodgkina}

Obecnym standardem leczenia chorych na chłoniaka Hodgkina (HL, Hodgkin lymphoma) we wczesnym okresie zaawansowania i bez masy bulky jest chemioterapia $z$ radioterapią lub bez niej. Ze względu na możliwe, wczesne i późne powikłania radioterapii stosowanie takiego leczenia u chorych $z$ postacią wczesną pozostaje przedmiotem kontrowersji. $Z$ tego powodu Park i wsp. [12] zaplanowali badanie (streszczenie 7508) w celu oceny zastosowania brentuksymabu vedotin (BV) jako konsolidacji leczenia według protokołu ABVD (doksorubicyna, winblastyna, bleomycyna, dakarbazyna), co powinno stanowić alternatywę dla radioterapii jako skuteczna i bezpieczna metoda eradykacji choroby resztkowej u chorych z postacią wczesną HL. Do badania II fazy włączano wcześniej nieleczonych pacjentów $z$ wczesną postacią HL, bez masy bulky, lecząc chorych zgodnie ze schematem AVBD, a następnie BV. Celem pierwszorzędowym badania była ocena odsetka chorych, którzy osiągają CRm ocenianą w PET-CT (wskaźnik Deauville $\leq 2$ ) po leczeniu ABVD i konsolidacji BV. Chorym podano 2-6 cykli ABVD, zależnie od czynników ryzyka i wyniku PET-CT w trakcie leczenia. Po około 6 tygodniach od zakończenia leczenia indukującego podawano $\mathrm{BV}$ w dawce $1,8 \mathrm{mg} / \mathrm{kg}$ mc. co 3 tygodnie przez 6 cykli.

Do badania, od kwietnia 2012 roku do grudnia 2015 roku, włączono 40 chorych; mediana wieku wyniosła 29 lat (19-67 lat), a czynniki niekorzystnego rokowania stwierdzono u $46 \%$ chorych. Ponad $90 \%$ otrzymało do 4 cykli ABVD, jednego chorego zaś napromieniono $\mathrm{z}$ powodu progresji choroby. Toksyczność 3. stopnia lub wyższa według WHO, związana $z$ leczeniem za pomocą BV, obejmowała neutropenię u 3 chorych, neuropatie obwodową $\mathrm{u}$ jednego i wysypkę również u jednego chorego. Doszło do jednego zgonu związanego $z$ sepsą i niewydolnością wątroby, co jest bardzo rzadkim, ale znanym powikłaniem terapii BV. Po 2 cyklach ABVD u $72 \%$ chorych stwierdzono negatywny wynik badania PET-CT, a po terapii BV negatywny wynik PET-CT potwierdzono u $90 \%$ chorych. Po obserwacji o medianie 12 miesięcy estymowane roczne PFS i OS wyniosły, odpowiednio, 91\% i $96 \%$.

$\mathrm{Na}$ tej podstawie autorzy stwierdzili, że BV wykazuje obiecującą aktywność i profil bezpieczeństwa w konsolidacji leczenia według protokołu
ABVD, co — być może - w przyszłości pozwoli uniknąć radioterapii u chorych $z$ wczesną postacią HL bez masy bulky. Oczywiście wnioski te mają charakter hipotezy, która wymaga zwalidowania w badaniu III fazy, prawdopodobnie o konstrukcji non-inferiority, $z$ dojrzałymi danymi, a zatem na wniosek o możliwości pominięcia radioterapii na korzyść konsolidacji BV po ABVD trzeba jeszcze poczekać wiele lat.

Tematem nieodłącznie związanym $z$ badaniami nad HL jest ocena roli badania PET-CT w ocenie zaawansowania, odpowiedzi na leczenie, decyzji o modyfikacji leczenia i określeniu rokowania. Casasnovas i wsp. [13] przedstawili wyniki badania (streszczenie 7509), w którym oceniano wyjściową całkowitą objętość metaboliczną (TMTV, total metabolic tumor volume) jako czynnik predykcyjny dla wyników leczenia. Analizy dokonano w grupie chorych z postacią zaawansowaną HL leczonych w badaniu AHL2011 LYSA. Autorzy zwrócili uwagę, że wyjściowa TMTV to stosunkowo nowe podejście do oceny masy guza, ale jego znaczenie dla wyników leczenia potwierdzono $\mathrm{w}$ badaniu retrospektywnym. W związku $z$ tym powstał projekt oceny wartości prognostycznej TMTV u chorych włączanych prospektywnie do randomizowanego badania III fazy, w którym decyzje terapeutyczne uzależniano od wyniku PET-CT w porównaniu $z$ tradycyjną metodą oceny odpowiedzi nieopartą na PET.

Do analizy włączono chorych uczestniczących w badaniu AHL2011, dla których przed leczeniem było dostępne badanie PET z możliwością oceny TMTV (PET0). Chorzy byli w wieku 16-60 lat i rozpoznano u nich zaawansowaną postać HL (wg Ann Arbor stopień III, IV lub IIB wysokiego ryzyka). Chorych poddano randomizacji do grupy leczonej zależnie od wyniku badania PET po 2 cyklach (PET2) - według schematu BEACOPP (bleomycyna, etopozyd, adriamycyna, cyklofosfamid, winkrystyna, prokarbazyna, prednizon) w eskalowanych dawkach (BEACOPPesc, BEACOPP escalated). W przypadku negatywnego wyniku PET2 kontynuowano leczenie 4 cyklami ABVD, a w przypadku pozytywnym wyniku PET2 podawano kolejne 4 cykle BEACOPPesc. U chorych $\mathrm{w}$ grupie leczonej standardowo nie wykonywano PET2 i podawano $z$ góry zaplanowane 6 cykli BEACOPPesc. Wynik PET2 oceniano centralnie $\mathrm{i}$ interpretowano zgodnie $\mathrm{z}$ kryteriami Deauville. $Z$ kolei TMTV wyliczano $z$ badania PET0, sumując objętość metaboliczną pojedynczych zmian, przyjąwszy za punkt odcięcia 41\% SUVmax, wcześniej uznany za referencyjny dla chłoniaków. 
Do analizy włączono 392 chorych, $z$ medianą wieku 30 lat. Mężczyźni stanowili 64\%; u 89\% stwierdzono III-IV stopień zaawansowania według Ann Arbor, a u 59\% IPS (International Prognostic Score) wynosił co najmniej 3. Mediana TMTV wyniosła $200 \mathrm{ml}$ (zakres 23-2149 ml). Dla dalszych analiz ustalono TMTV w grupie treningowej (262 chorych) na $350 \mathrm{ml}$, a potwierdzono tę wartość w serii walidacyjnej (130 chorych). Po obserwacji o medianie 16 miesięcy w całej grupie chorych 2-letnie PFS wyniosło $81 \%$ i $93 \%$, odpowiednio, u chorych $z$ małą i dużą TMTV $(\mathrm{p}=0,0015 ; \mathrm{HR}=3)$. Pozytywny wynik PET2 wiązał się $z$ niższym odsetkiem 2-letniego PFS w porównaniu $z$ chorymi, u których wynik PET2 był negatywny (76\% v. 92\%; $\mathrm{p}<0,0001)$. Na tej podstawie zidentyfikowano trzy grupy: 1. $z$ małą TMTV i pozytywnym wynikiem PET2 $(\mathrm{n}=23 ; 6 \%)$ lub dużą TMTV i negatywnym wynikiem PET2); 2. z małą TMTV i pozytywnym wynikiem PET2 $(\mathrm{n}=103 ; 27 \%)$; $3 . \mathrm{z}$ małą TMTV i negatywnym wynikiem PET2 $(n=261 ; 67 \%)$. Odsetek 2-letniego PFS wyniósł w tych grupach, odpowiednio, $61 \%, 88 \%, 94 \%$ ( $<00,0001$ ).

Autorzy pracy wysnuli wniosek, że TMTV jest czynnikiem predykcyjnym dla przebiegu klinicznego $\mathrm{u}$ młodych chorych na zaawansowaną postać HL niezależnie od wyniku PET2. Połączenie wartości predykcyjnej TMTV i PET2 pozwala na identyfikację trzech podgrup chorych o odmiennym rokowaniu, co pozwoli zindywidualizować leczenie. Problem identyfikacji chorych wymagających wczesnej intensyfikacji leczenia HL pozostaje obecnie nierozwiązany; TMTV wydaje się dostarczać dodatkowych informacji prognostycznych u chorych na HL.

Nowa koncepcja leczenia nowotworów - stosowanie inhibitorów punktów kontroli odpowiedzi immunologicznej, które w ostatnich latach pozwoliło poprawić wyniki leczenia w guzach litych - ma także swoje miejsce w terapii HL. Younes i wsp. [14] (streszczenie 7535) przedstawili wyniki badania CHECKMATE 205. W klasycznym HL występuje amplifikacja 9p24.1 powodująca nadekspresję ligandów PD-1 (programmed cell death protein 1), zatem stosowanie przeciwciał anty-PD-1 potencjalnie wiąże się $z$ wysoką skutecznością. Niwolumab jest w pełni ludzkim IgG4 inhibitorem punktu kontrolnego, w odniesieniu do którego wykazano skuteczność w badaniu fazy Ib $u$ pacjentów $z$ opornością lub nawrotem choroby [15]. Do CHECKMATE 205, badania II fazy, włączono chorych po leczeniu BV z powodu niepowodzenia po auto-HSCT w celu oceny skuteczności i bezpieczeństwa niwolumabu. Niwolumab podawano dożylnie, w dawce $3 \mathrm{mg} / \mathrm{kg}$ mc. co 2 tygodnie. Odpowiedź określano zgodnie $z$ kryteriami IWG 2007, zarówno w ocenie badacza, jak i w ocenie centralnej. Głównym punktem końcowym badania był ORR. Wśród 80 włączonych chorych z klasycznym HL mediana wieku wyniosła 37 lat, a mediana wcześniejszych linii leczenia była równa 4 (zakres 3-15). U 90\% chorych wystąpiły objawy niepożądane związane $z$ leczeniem, przy czym objawy 3.-4. stopnia według WHO u 25\% chorych oraz u 1\% w stopniu G5 (niewydolność wielonarządowa). Najczęstszymi działaniami niepożądanymi związanymi $z$ leczeniem były zespó1 zmęczenia (25\%), reakcje związane $z$ wlewem (20\%) i wysypka (16\%). Najczęstszymi ciężkimi zdarzeniami niepożądanymi były gorączka, progresja chłoniaka, arytmia, reakcja związana $z$ wlewem, septyczne zapalenie opon mózgowo-rdzeniowych i zapalenie płuc (każde $\leq 4 \%$ ). Immunologiczne działania niepożądane wystąpiły u $26 \%$ chorych. W chwili zamknięcia bazy danych mediana obserwacji wynosiła 8,9 miesiąca (zakres 1,9-11,7 miesiąca). Leczenie prowadzono u $64 \%$ chorych; głównymi przyczynami przerwania leczenia niwolumabem była progresja chłoniaka (16\%). W niezależnej ocenie centralnej ORR wyniósł 66\% (95\% CI, 54,8-76,4), odsetki CR i PR natomiast wyniosły, odpowiednio, $8,8 \%$ i $57,5 \%$. U 6 chorych przerwano podawanie niwolumabu, aby przeprowadzić HSCT; wszyscy ci chorzy żyli $\mathrm{w}$ chwili analizy. Zgodnie $z$ oceną centralną 6 -miesięczne PFS wyniosło 77\%, a OS 99\%. Ponadto u 43 chorych, u których leczenie BV nie przyniosło odpowiedzi, niwolumab okazał się skuteczny, z ORR wynoszącym $72 \%$ (31/43 chorych).

Autorzy stwierdzili, że niwolumab jest skuteczny i bezpieczny, powodując wysokie odsetki odpowiedzi, długi czas trwania odpowiedzi u chorych $z$ klasycznym HL, po auto-HSCT i BV, łącznie z chorymi, którzy nie odpowiedzieli na BV. Co więcej, pierwsza ocena PFS i OS budzi nadzieję na skuteczne leczenie ciężko przeleczonych chorych na HL, dla których do tej pory nie było równie aktywnej alternatywy.

$Z$ wielu innych badań klinicznych w guzach litych wiadomo, że niwolumab jest lekiem bezpiecznym, nawet jeśli terapia trwa kilka lat. Ponadto $z$ dostępnych danych pochodzących $z$ badań III fazy wynika, $\dot{z}$ e leczeniu niwolumabem nie towarzyszy pogorszenie jakości życia, co ma szczególne znaczenie dla chorych leczonych paliatywnie. 


\section{Podsumowanie}

Podsumowując, wyniki badań prezentowanych na konferencji ASCO 2016 zapewne nie będą źródłem zmiany codziennej praktyki klinicznej, ale nawet negatywne wyniki czy wstępne analizy badań wzbogacają wiedzę na temat chłoniaków. Natomiast interesującymi i wartymi wprowadzenia do codziennej pracy są badania wskazujące na rolę leczenia przeciwwirusowego $\mathrm{u}$ chorych z HCV i DLBCL, wartości TMTV w ocenie PET-CT oraz nowa koncepcja leczenia HL za pomoca niwolumabu.

\section{Piśmiennictwo}

1. Witzig T.E., Tobinai K., Rigacci L. i wsp.; PILLAR-2: A randomized, double-blind, placebo-controlled, phase III study of adjuvant everolimus (EVE) in patients (pts) with poor-risk diffuse large B-cell lymphoma (DLBCL). J. Clin. Oncol. 2016; 34 (supl.): abstrakt 7506.

2. Lugtenburg P.J., de Nully Brown P., van der Holt B. i wsp. Randomized phase III study on the effect of early intensification of rituximab in combination with 2-weekly $\mathrm{CHOP}$ chemotherapy followed by rituximab or no maintenance in patients with diffuse large B-cell lymphoma: results from a HOVON-Nordic Lymphoma Group study. J. Clin. Oncol. 2016; 34 (supl.): abstrakt 7504.

3. Kurtz D.M., Scherer F., Newman A.M. i wsp. Prediction of therapeutic outcomes in DLBCL from circulating tumor DNA dynamics. J. Clin. Oncol. 2016; 34 (supl.): abstrakt 7511.

4. Crump M., Swarup Neelapu S., Farooq U. i wsp. Outcomes in refractory aggressive diffuse large b-cell lymphoma (DLBCL): results from the international SCHOLAR-1 study. J. Clin. Oncol. 2016; 34 (supl.): abstrakt 7516.

5. Hosry J., Mahale P., Turturro F. i wsp. Effect of antiviral therapy on overall survival in hepatitis c virus-infected patients with diffuse large B-cell lymphoma. J. Clin. Oncol. 2016; 34 (supl.): abstrakt 7540

6. Rubenstein J.L., Fraser E., Formaker P. i wsp. Phase I investigation of lenalidomide plus rituximab and outcomes of lenalidomide maintenance in recurrent CNS lymphoma. J. Clin. Oncol. 2016; 34 (supl.): abstrakt 7502.

7. Scott D.W., Abrisqueta P., Wright G. i wsp. Prognostic significance of the proliferation signature in mantle cell lymphoma measured using digital gene expression in formalin-fixed paraffin-embedded tissue biopsies. J. Clin. Oncol. 2016; 34 (supl.): abstrakt 7510.

8. Rummel M.J., Knauf W., Goerner M. i wsp. Two years rituximab maintenance vs. observation after first-line treatment with bendamustine plus rituximab (B-R) in patients with mantle cell lymphoma: first results of a prospective, randomized, multicenter phase II study (a subgroup study of the StiL NHL7-2008 MAINTAIN trial). J. Clin. Oncol. 2016; 34 (supl.): abstrakt 7503.

9. Evens A.M., Hong F., Habermann T.M. Effect of bortezomib on complete remission (CR) rate when added to bendamustine-rituximab (BR) in previously untreated high-risk (HR) follicular lymphoma (FL): a randomized phase II trial of the ECOG-ACRIN Cancer Research Group (E2408). J. Clin. Oncol. 2016; 34 (supl.): abstrakt 7507.

10. Trumper L.H., Wulf G., Ziepert M. i wsp. Alemtuzumab added to $\mathrm{CHOP}$ for treatment of peripheral T-cell lymphoma (pTNHL) of the elderly: final results of 116 patients treated in the international ACT-2 phase III trial. J. Clin. Oncol. 2016; 34 (supl.): abstrakt 7500 .

11. Mounier N., Anthony S., Busson R. Long term toxicity and fatigue after treatment for non-Hodgkin lymphoma (NHL): an analysis of twelve Collaborative Lymphoma Study Association (LYSA) trials, the Simonal Study. J. Clin. Oncol. 2016; 34 (supl.): abstrakt 7518.

12. Park S.I., Olajide O.A., Reddy N.M. A phase 2 trial of ABVD followed by brentuximab vedotin consolidation in limited stage non-bulky Hodgkin lymphoma. J. Clin. Oncol. 2016; 34 (supl.): abstrakt 7508.

13. Casasnovas R.O., Kanoun S., Tal I. i wsp. Baseline total metabolic volume (TMTV) to predict the outcome of patients with advanced Hodgkin lymphoma (HL) enrolled in the AHL2011 LYSA trial. J. Clin. Oncol. 2016; 34 (supl.): abstrakt 7509.

14. Younes A., Santoro A., Zinzani P.L. Checkmate 205: nivolumab (nivo) in classical Hodgkin lymphoma (cHL) after autologous stem cell transplant (ASCT) and brentuximab vedotin (BV) a phase 2 study. J. Clin. Oncol. 2016; 34 (supl.): abstrakt 7535.

15. Ansell S.M., Lesokhin A.M., Borrello I. i wsp. PD-1 blockade with nivolumab in relapsed or refractory Hodgkin's lymphoma. N. Engl. J Med. 2015; 372: 311-319. 